\title{
Music and Merchants: The Laudesi Companies in Early Renaissance Florence
}

\author{
BLAKE WILSON
}

In 1255 the Council of Bordeaux defined the place of lay religious confraternities within ecclesiastical organization, prescribing pious activities that ranged from collecting alms and assisting with Mass to repairing bridges and chasing away wolves. ${ }^{1}$ The Church's concept of a valid religious life tended then, as before, to relegate the laity to a passive and servile role. In so doing it underestimated their needs and aspirations, particularly those of the politically and socially activated laity in Europe's burgeoning cities who sought a religious life commensurate with their active cosmopolitan lives. Nowhere in the Bordeaux Council's list is there a hint of what was actually taking place at that moment in the city republics of central Italy, where autonomous lay groups were developing vernacular services and liturgies that imitated, and would come to rival, their clerical counterparts.

No aspect of this parallel development is as indicative of the layman's aspirations as the 13th-century appearance of the lauda repertory, which would remain for centuries the most popular type of vernacular religious lyric in central Italy. As the vast lyrical repertory of chant was to the Latin liturgy, so was the lauda to the vernacular services of the laudesi companies. ${ }^{2}$ The "compagnie delle laude" were groups of laymen (and sometimes women) organized primarily under the auspices of the Dominican, Franciscan, and other mendicant orders to receive religious instruction, provide charitable services for the poor, and above all to conduct their own liturgical services that featured the devotional activity of lauda singing. It is here, as the lyrical core of a lay, vernacular liturgy, that the lauda arose, attained a stable musico-poetic form, and became the dominant insignia of the lay religious activism fostered by the mendicant orders. 
EXAMPLE 1: Syllabic Lauda for the Feast of St. Dominic
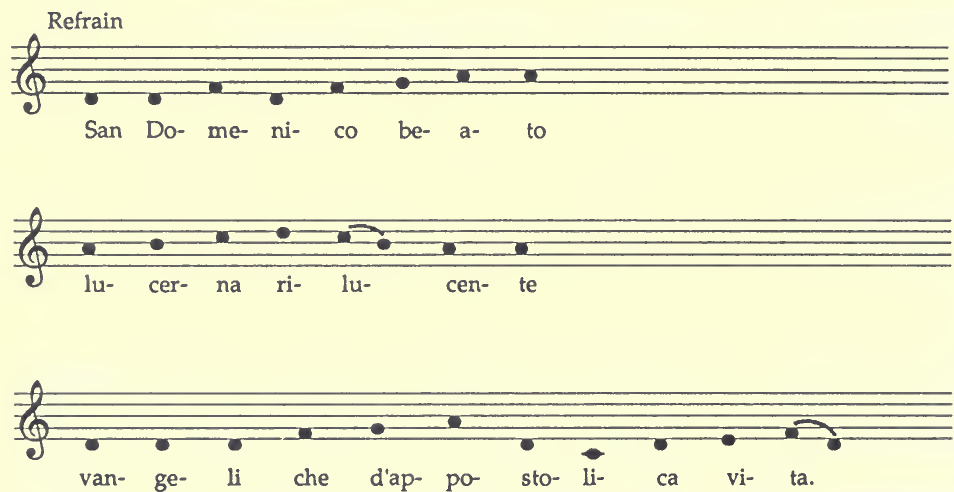

Strophe
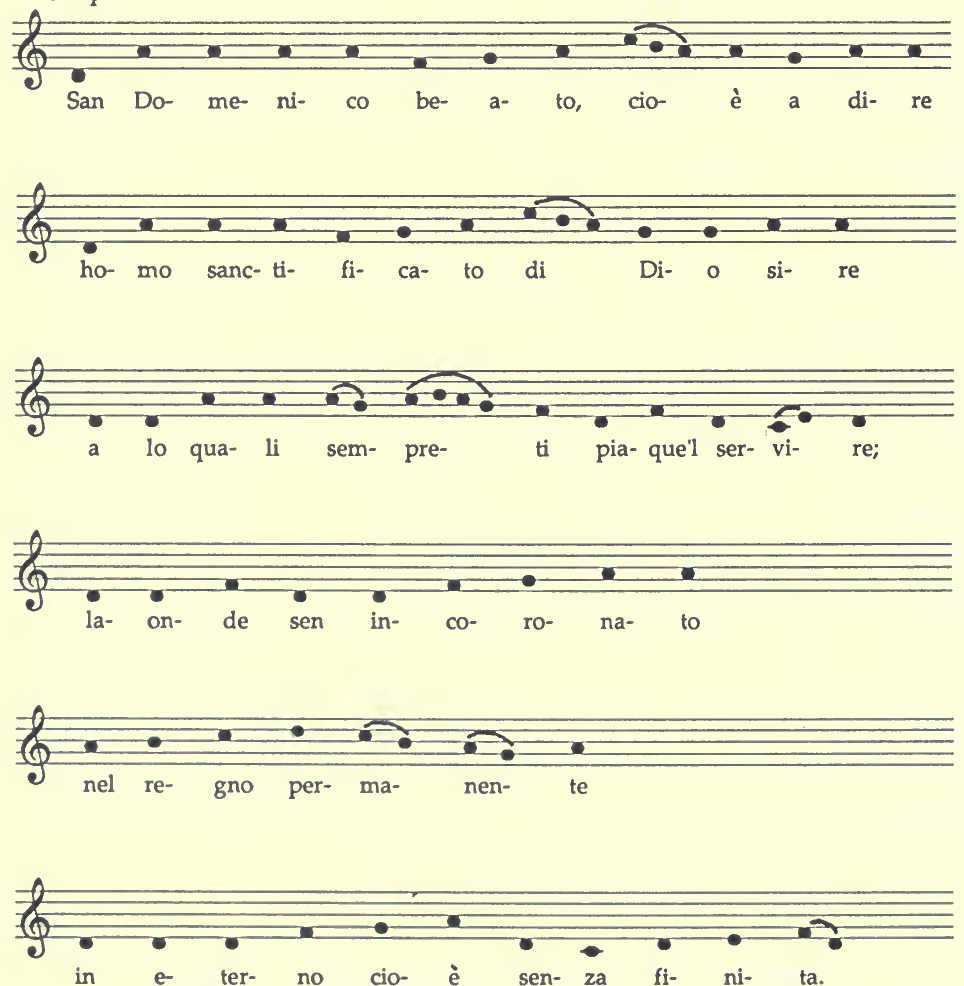
EXAMPLE 2: Florid Lauda for the Feast of St. Dominic

Refrain

Al- le- gro
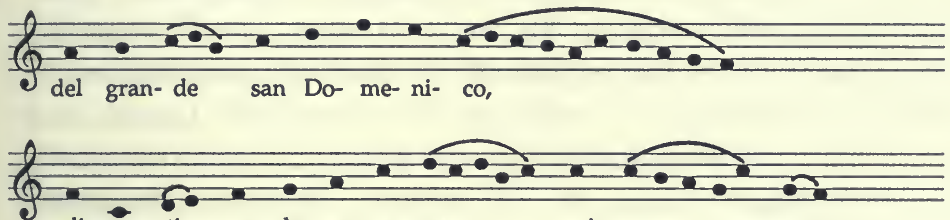

di tan- ti va- lo- ro- so ca- pi- ta- no.
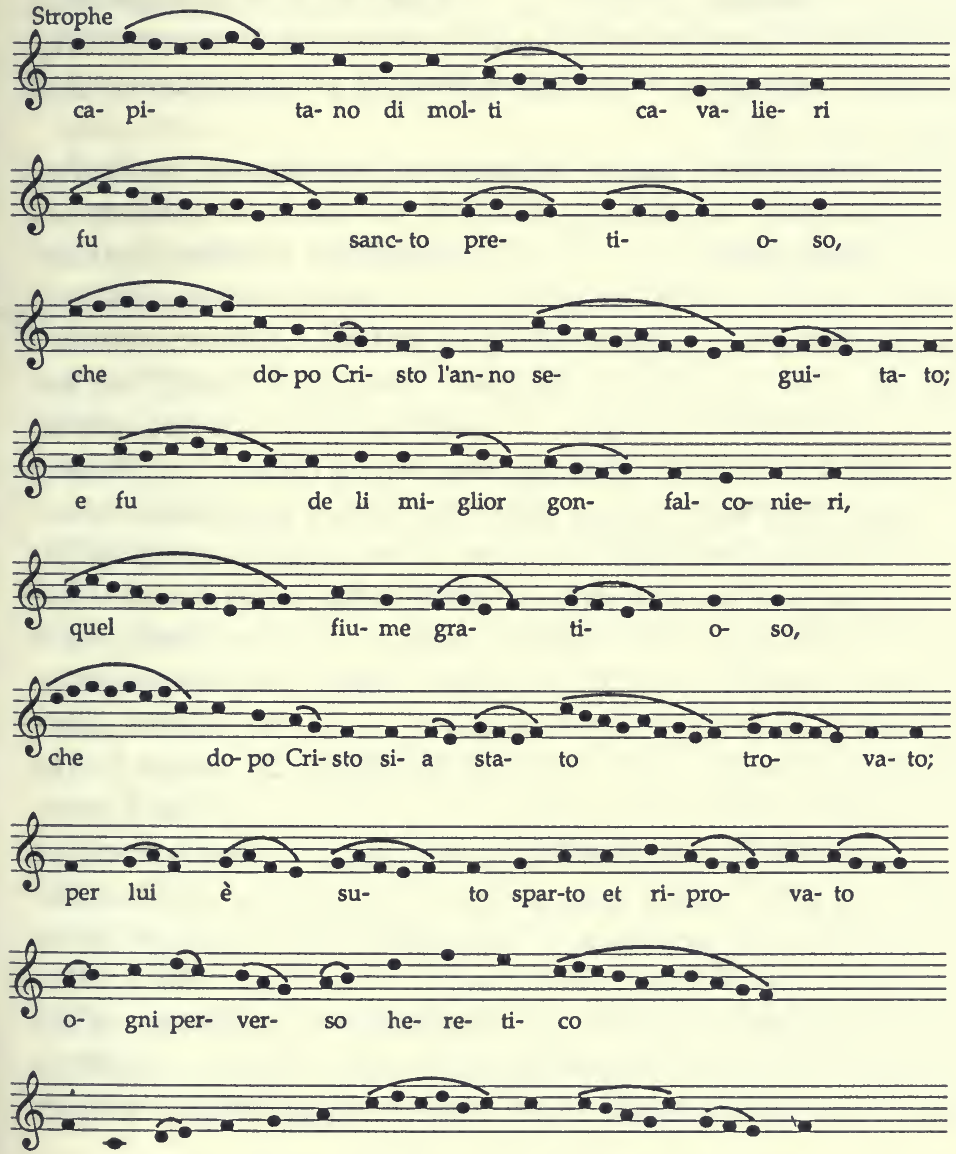

che nel- la fe- de tro- vas- se lon- ta- no.


The laudesi companies, along with their penitential counterpart, the disciplinati (or flagellant) companies, were the distinctive result of the interaction between the forces of mendicant spirituality, urban piety, and the merchant culture of the early Italian city republics. ${ }^{3}$ For nearly two and a half centuries the companies flourished in the bustling mercantile centers of Tuscany and Umbria. The heartland of laudesi activity was Florence. During the period when most of the laudesi companies were founded, ca. 1270-1340, Florence was the largest city in Europe, excelling in its mercantile activity, the number and greatness of its mendicant houses, and in the strength of its republican government, of which Florence was to be among the last strongholds in the early 16 th century. These were favorable conditions for the lauda and the laudesi; numerous Florentine poets from anonymous artisans to Lorenzo de' Medici contributed to a vast repertory, and the Florentine companies were the wealthiest, most numerous, and most enduring of their kind.

What survives of the early lauda repertory is preserved in the service books of the companies, the laudari, in which the laude were organized liturgically according to the Proper of the Time (Advent, Lent, etc.) and the Proper of the Saints (Feast of St. Augustine, etc.). Most laudari contained only the texts; fewer the monophonic melodies as well. Of these latter two have survived: the late 13 th-century Cortona manuscript (Cort), ${ }^{4}$ an unadorned book containing 45 melodies in a predominantly simple, syllabic style; and the early 14th-century Florence manuscript (Mgl1), ${ }^{5}$ an elegant, illuminated collection of 88 melodies, many of them of such florid nature that one scholar has observed "that [they] must have required considerable virtuosity on the part of the performers." 6 Music examples 1 and 2 are transcriptions of two laude to St. Dominic, whose order was particularly strong in Florence. The first typifies the older Cortona melodies, with its simple, declamatory style and narrow melodic range; the second, from among a group of more recently composed laude to the saints in the Florence manuscript, honours the saint with a much longer and more virtuosic piece. ${ }^{7}$ Such florid melodies did not issue from an clite performing tradition within the city's laudesi companies, for the Florence manuscript belonged to the Company of Santo Spirito, which was very modest by Florentine standards (see Table 1). The wealth of the Florentine laudario and the technical aspect of its laude point to the particular history of the Florentine companies that will be examined here-their rapid development into prosperous and stable institutions with professional musical chapels 
staffed by singers and instrumentalists who specialized in the performance of laude.

The material success of the companies was due in part to the fact that they were managed by some of the most skilled businessmen in Western Europe-Florentine merchants. In addition, the influential mendicant preachers exhorted them to perceive and practice their faith in terms of

TABLE I: The Florentine Laudesi Companies ${ }^{8}$

\begin{tabular}{|c|c|c|c|}
\hline Company & Church & Order & Assets \\
\hline $\begin{array}{l}\text { Orsanmichele } \\
\text { (est. 1291) }\end{array}$ & Orsanmichele & lay & 14,947 \\
\hline $\begin{array}{l}\text { S. Piero Martire } \\
\text { (by } 1288 \text { ) }\end{array}$ & Santa Maria Novella & Dominican & 11,362 \\
\hline $\begin{array}{l}\text { San Zanobi } \\
(1281)\end{array}$ & Cathedral & Diocesan & 2,146 \\
\hline $\begin{array}{l}\text { Sant'Agnese } \\
\text { (by } 1280 \text { ) }\end{array}$ & S. Maria del Carmine & Carmelite & 593 \\
\hline $\begin{array}{l}\text { San Gilio } \\
(1278)\end{array}$ & San Gilio & Sacchite & 358 \\
\hline $\begin{array}{l}\text { Santo Spirito } \\
\text { (by 1322) }\end{array}$ & Santo Spirito & $\begin{array}{l}\text { Augustinian } \\
\text { (friars) }\end{array}$ & 285 \\
\hline $\begin{array}{l}\text { San Lorenzo } \\
\text { (by 1314) }\end{array}$ & San Lorenzo & Collegiate & 123 \\
\hline $\begin{array}{l}\text { San Frediano } \\
\text { (ca. 1370) }\end{array}$ & San Frediano & Cistercian & 76 \\
\hline $\begin{array}{l}\text { San Marco } \\
\text { (by 1329) }\end{array}$ & San Marco & $\begin{array}{l}\text { Dominican } \\
\text { (observant) }\end{array}$ & 42 \\
\hline $\begin{array}{l}\text { San Bastiano } \\
\text { (by 1273) }\end{array}$ & Santissima Annunziata & Servite & \\
\hline $\begin{array}{l}\text { Santa Croce } \\
\text { (by 1282) }\end{array}$ & Santa Croce & Franciscan & \\
\hline $\begin{array}{l}\text { Ognissanti } \\
(1336)\end{array}$ & Ognissanti & $\begin{array}{l}\text { Franciscan } \\
\text { (observant) }\end{array}$ & \\
\hline
\end{tabular}


their daily mercantile experience. Merchants and artisans might regard Christ as a bonus negotiator who traded in the more valuable riches of heaven, to regard Lent as a great trade fair where spiritual profit (grace through confession) could be made; like their secular counterparts the companies were indeed a kind of sacred business run for purpose of earning shared spiritual profits. ${ }^{9}$ The laudesi companies were modeled on guild structures: they elected officers, paid dues, met regularly, drew up statutes regulating corporate activity, and maintained meticulous account books. It would not have escaped the friars' notice that the guild structure, as a door to a higher world of secular political and social activity, was eminently suited to a spiritual reinterpretation. Through lauda singing directed to the Saints, members cultivated sacred connections with their divine advocates and earned indulgences, precisely numbered days of spiritual credit to be applied against the long-standing penitential debt expressed in the concept of Purgatory.

The widespread belief in the efficacy of lauda singing (bolstered by papal indulgences) led to its popularity, and it was the popularity of the devotion that in turn led to the material success of the companies. Writing in the early 14th century, the Florentine chronicler Giovanni Villani described this transition from a spontaneous devotion to a wealthy institution as it was experienced by the Company of Orsanmichele:

In that year [1292], on the 3rd of July, there began to be manifested great and sincere miracles in the city of Florence by a figure of the Virgin Mary painted on a pilaster of the loggia of Orto San Michele, where the grain is sold ... out of custom and devotion, a number of laity sang laude before this figure, and the fame of these miracles, for the merits of Our Lady, so increased that people came from all over Tuscany in pilgrimage... and since [its membership] was the greater part of the buona gente of Florence, the state of this Company so improved that the many benefits and alms of bequests for the poor amounted to more than 6000 lire.... ${ }^{10}$

By the 1340 s, a strong institutional framework had grown up around the devotion of lauda singing, which had bccome a profession for the singers (and instrumentalists) as well as a business for the companies.

There were twelve laudesi companies in 14th-century Florence (Table I). Ten of them had been established by 1329 , in which year they are listed in a collective petition to the city where they refer to themselves as the "Greater Companies of the Blessed Mary of Florence," an indication that they were the principal lay guardians of the Virgin's cult in Florence. ${ }^{11}$ By this time 
the companies were well established in the major Florentine churches. A laudesi company usually owned the patronage rights to one, sometimes two, altars in its host church, and depending on the company its altar might be located in the nave, transept, or apse. Like a secular patron, the company usually assumed responsibility for the construction, repair, and decoration of its altar, and the companies were a major source of commissions for Florentine artists. Like a chaplain, the companies conducted the ritual obligations associated with its altar, hiring clergy to recite Masses and Offices, and lay singers, the laudesi, to sing in their vernacular lauda services.

The companies maintained three types of service: processional, ferial, and festive. The procession service was a candle offering that took place one Sunday a month either during or after Mass. According to its 1326 statutes, the Cathedral company of San Zanobi processed two by two during the Offertory, bearing lighted candles and singing a lauda. ${ }^{12}$ The statute describes a responsorial performance, with two singers at the head of the procession performing the soloistic strophes, and the remainder of the company "singing and responding" on the choral refrains.

The festive and ferial services took place in the evening on or shortly after the designated hour of Compline. Lauda singing was directed to a devotional image upon the company altar, and was the central activity in a service that included prayers, readings, and a brief sermon and confession conducted by a priest or friar retained by the company as their spiritual advisor. A company sacristan set up for the services, selecting from among various sizes and grades of candles, laudari, lecterns (from which the soloists sang), and altar cloths, according to the liturgical solemnity of the service. The ferial services took place every evening of the week; a typical prescription is that from the 1326 statutes of the Company of San Zanobi:

We ordain and establish that everyone of this Company is to meet every evening in the aforesaid church of the Madonna Santa Reparata [the old Cathedral] to sing some laude ("a chantare alchune laude") with the Ave Maria to the honour of God and Our Lady. ${ }^{13}$

In their festive services the companies celebrated the annual feasts of the liturgical cursus with a vigil service on the eve before the feast, attendance at Mass and preaching the morning of the feast, and on the most solemn occasions another vigil that evening. These services were in fact called "vigilie alle laude," lauda vigils, or sometimes "luminaria alle laude" since the entire company held and offered lighted candles during the service. The 
company singers performed special laude proper to the feast, which were to be found in a large, festive laudario (like the Florence manuscript), as opposed to smaller ferial books which probably lacked notation and illumination, and contained what were called "laude commune" for singing throughout the year. ${ }^{14}$ On the most important occasions, like the feast of a patron saint, a company hired extra singers, municipal wind and brass players, and in the larger companies players of vielle, rebec, lute, and harp who accompanied the singing of laude.

Each company had also begun by the early 14 th century to maintain a weekly school for the teaching of laude. Every Sunday afternoon specially appointed lauda instructors (or "governors") taught and rehearsed the refrains of laude with company members, and it appears that these instructors supervised the lauda performances during the evening services, as well. According to a 1333 statute of the Company of Orsanmichele,

The duty of the governors of the laude is to arrange and order how the laude are to be sung every evening before the image of Our Lady on the pilaster beneath the loggia, and to conduct the school on Sundays to learn [the laude], and for which reason they [themselves] are to learn to sing the laude. And they are to sing in the Oratory of the Company before the image of Our Lady... [and] the laudesi are to obey these governors according to the statutes. ${ }^{15}$

By the early 14th century, the Florentine laudesi companies had within 50 years developed an administrative burcaucracy that included captains, counsellors, treasurers, bill collectors, and company lawyers, and a complex vernacular liturgy complete with specialized liturgical paraphernalia, service books, paid clerics and musicians, and a repertory of sacred song that spanned the entire church year. The companies had developed rapidly since the days of spontaneous lauda singing by unpaid, in-house singers, and this was due largely to the bequests that this popular devotion began to attract.

The Company of San Piero Martire, one of the oldest and wealthiest in the city, recorded its first bequest in 1299; by 1421 the Company was managing some 93 bequests. ${ }^{16}$ The other companies received most of their bequests during this period, and their varying degrees of success are reflected in the assets listed in Table 1.

A bequest was generally made by a company member or neighborhood resident, who had willed to the company a house or farm, the annual proceeds of which were to be divided among various kinds of commemorative service and charity. In this respect, the companies acted primarily as 
the executors of the will, and their corporate stability and business acumen made them attractive clients. The commemorative services requested were often those of clerics, either a commemorative Mass (rinovale) or a commemorative meal (piatanza), which the company simply administered. But a will might also call for the vernacular counterpart of these services: a commemorative lauda vigil, sometimes called a "rinovale alle laude" (in which case a Mass was interpolated into the lauda vigil and clerics were hired), or a collazione (a meal that was the equivalent of the clerical piatanza). Most bequests called for various combinations of these services, and the networks of spiritual benefits engaged by the companies' merchant clients reflect the latter's intention to be as careful with their spiritual investments as they had been with their temporal ones. Orlandino Lapi was a wealthy silk merchant who lived in the working class neighborhood of San Frediano, across the river in the oltrarno district. When he died in 1$\lrcorner 86$, his will provided for commemorative services by the friars of Santa Croce and Santa Maria Novella, the two great city-wide churches. But his neighborhood loyalty was revealed through generous bequests to the Carmine friars, and for lauda vigils by the laudesi companies of the Carmine and Santo Spirito, the two major churches in his quarter of the city. ${ }^{17}$

One of the earliest datable lauda bequests was made in 1313 by a silk merchant named Michele to the Company of San Zanobi (SZ 2170, f. 1v). The rent of a house was to provide for the annual distribution of bread to the poor on the morning of the feast of St. Thomas (Dec. 21), and for a lauda vigil on the feast of his namesake, St. Michael. Most bequests combined some form of commemorative service and meal. In 1415, a bequest to the small Company of San Frediano by frate Giovanni Lozi provided that

... from this time every year in perpetuity on the first Sunday after the [feast] day of San Frediano, laude are to be sung in the church of San Frediano with a vigil for the soul of the said fra Giovanni. Afterwards, according to custom, chestnuts are to be given out. And in the evening among our company there is to be a collazione for the priests, the laudiere (lauda singers), and the men of the Company, at a total cost of around 8 lire. $^{18}$

A similar bequest was made to the Company of Sant'Agnese by Mona Filippa di Grano, for a lauda vigil and commemorative meal on the Company's patron saint's feast day. The commemorative meal included not only the Company's singers (which was customary), but all the laudesi of 
Florence ("tutti i chantori delle laude di firenze"). In 1446, the lauda singers of Florence consumed honey, fennel, puff pastries, and white wine in grateful memory of this pious woman (SA 24, f. 15v).

The same company received a more complex bequest in 1377 from Chiaro d'Ardinghelli, a wealthy merchant and company member. Chiaro left the Company a farm with buildings, vineyards, and olive orchards, plus a yearly basket of beans for the Company's annual Ascension feast. The property generated 56 lire per year, which the Company was to distribute in perpetuity in the following manner:

1. 12 lire for a commemorative meal on March 25, the feast of the Annunciation.

2. 10 lire for a solemn Mass on Dec.6, the feast of St. Nicholas;

3. 12 lire for another commemorative meal on Dec.8, the feast of the Immaculate Conception;

4. 12 lire for bread to be distributed on Christmas day to the poor of the neighborhood;

5. 6 lire for a lauda vigil in August "a modo usato";

6. And 4 lire to the nearby Company of San Frediano for another lauda vigil in August, the month of Chiaro's death (SA 29, f.3).

There is a brief but interesting history bchind this last item. The Company of San Frediano was not a laudesi company at its founding in 1326, but between 1368 and 1373 the Company records show detailed expenses for a decorated laudario, lectern, and altar paraphernalia. What transpired between the Company's founding and its decision to become a laudesi company were the steadily growing popularity of lauda singing as a commemorative devotion, and the Black Death, which struck Florence in the spring of 1348 and swiftly killed about two-thirds of the city. Thereafter the Company's records are silent for over a decade, but it slowly revived in the 1360 s, and by the early 1370 s its resources permitted the acquisition of its lauda singing equipment. In 1377, the Company received its first recorded bequest for a lauda vigil from one of its long-time leaders, Chiaro d'Ardinghello. There is no reason to doubt the picty of Chiaro and his fellow Company officers, and the experience of the Plague (and its recurrences) certainly impressed upon them the propricty of engaging in commemorative devotions. But these were also professional businessmen who must have recognized the material virtues of bequests, both as a means of assuring the Company's survival in a most uncertain world, and as a 
rapidly expanding market in which the Company might compete to advantage. In fact, advantage came quickly. In the following decades membership grew, more bequests were made, two more laudari were acquired, and numerous expenses for altar repair and decoration reveal the expansion of the altar-oriented ritual life characteristic of laudesi devotion.

These bequests rested on the belief that lauda singing, like other forms of commemorative devotion, were efficacious, that is, they effectively safeguarded the soul of the deceased in its journey into another world, hastened its release from Purgatory, and supplicated it in its role as intercessor. Laudesi company statutes and bequest records continually reaffirm the "great spiritual and temporal utility" that was generated by their commemorative lauda vigils, which were clearly understood to be for the "rimedio dell'anima" of the deceased. However, the satisfactory fulfilment of the terms of a bequest was a legal as well as spiritual matter, and this greatly influenced the institutional structure that rose up around the devotion. A poor or negligent exccution of the terms of a bequest could lead to shame for the Company and legal diversion of the bequest to another institution (these alternates were usually designated in the will). Conversely, the more satisfactory the execution, the more likely the attraction of future bequests, especially since liturgical splendour was believed to contribute to the efficacy of the devotion. And for these singing companies, satisfactory fulfilment above all required the services of able and dependable singers. The Company of Orsanmichele maintained the largest laudesi chapel in the city, indeed the largest musical establishment in Florence throughout the 14 th and 15th centuries, in accordance with its status as one of the city's wealthiest institutions. In the Company's 1427 catasto report, at the head of a long list of fiscal obligations, are noted the Company's full-time musicians:

1. 6 laudesi who sing laude every day at L. 180 per year,

2. 6 laudesi who sing laude on feast days at L. 144 per year,

3. 2 players of vielle and lute at L. 60 per year,

4. Ser Piero who plays the organ at L. 66 per year. ${ }^{19}$

This was an exceptional musical establishment; the other companies usually hired two to three singers per service at this time, and the only other company that frequently hired instrumentalists was San Zanobi.

In Florence, the professional laudesi first appeared in the early 14th century, along with the earliest bequests for lauda vigils. For the next two centuries the city's companies were served by a large body of freclancing 
singers who performed in the companies' services on a strictly contract basis.

Although account books survive for only six of the city's twelve companies, it is clear that the most active singers freelanced widely. A few were omnipresent, like Nocho d'Alesso, a weaver who sang for all six companies between 1441 and 1464. Many names appeared for only a brief period in the records of one company, but these short careers constituted a peripheral activity. The companies were most often served by singers whose period of service to a single company might vary from several months to many years, but who usually sang for two or more companies, and whose singing careers stretched from their adolescence to their 70 s, usually lasting between ten and fifty years. ${ }^{20}$

Throughout the 14th and 15th centuries, the Florentine laudesi were typically lower guildsmen, artisans involved in a local trade. They were bakers, carpenters, goldsmiths, barbers, lanternmakers, but most were involved in the great Florentine wool industry: washers, dyers, and independent master weavers, clothcutters, and burlers. For them lauda singing was a supplemental income that more or less paid the annual rent on their dwelling, although some owned their own house and land. For some, perhaps one in six, lauda singing was a full-time profession, though not a very lucrative one. Out of twelve singers and one instrumentalist whose individual tax reports were traceable in the 1427 Catasto, the declared professions included three weavers, a clothcutter, a butcher, a barber, a glovemaker, a vielle player, two laudesi, and one who listed two professions: cloth burling and lauda singing. ${ }^{21}$

Of these twelve all but one lived in a rented house. Over half, including the two professional laudesi, were listed as "miscrabile," the tax assessor's term for a family that owned too little property to be subjected to a property tax, which is what the Catasto was. Most of these singers at one time or another performed with a son or a brother, and this family aspect was common to all Florentine laudesi activity. Numerous instances of fathers, sons, and brothers are evident among the 14th and 15th-century Company payrolls, a phenomenon which reflects a close-knit guild society in which specialized trade skills were a matter of family pride and patrimony. Father/son pairs appear frequently, and it was probably in this form of master/apprentice relationship that laudesi skills were most frequently transmitted. As in other trades, a son trained in a craft was an asset to his father; when the Company of San Zanobi was cutting back laudesi salaries 
in 1433, the singer Guasparre d'Ugolino Prosperi regained his precentor's wage on the condition that he would "bring his son to the laude [services]" (SZ 2186, f. 83v).

Brothers, both as boys and adults, also tended to perform together in pairs. But the obvious tendency of laudesi to circulate among the companies in pairs was not governed solely by family tics. Pairs of singers, related or not, some of whom journeyed together among the companies, remained the norm from the early 14 th century to the 1460 s. During the early 15 th century, the four largest companies had begun to hire three to six singers for their services, but pairs of singers remained the traditional unit. In the older monophonic repertory, this suggests the possibility that two singers may have alternated on the soloistic strophes, which could be quite numerous. They also probably combined to sing the choral refrains, from which company congregations were excluded by the virtuosity of many monophonic laude, and by the special skill required to sing the two-part polyphonic laude that appeared in the early 15th century. Only in the 1460s did this change, when the companies began hiring small polyphonic choirs of between five and eleven singers.

The relationship between the singers and the companies was strictly business. The company officers elected the singers, and drafted contracts which stipulated a monthly salary, length of service (usually three or four months), and obligations (such as performance at festive or ferial services, and sometimes sacristan duties). The stiff legal prose of these documents occasionally admits a few statements revealing the Company's concern with the quality of a singer. When the Company of San Frediano elected two singers to perform during Lent of 1441 , the contract stated that

... having elected and arranged for two [singers] to sing laude in the said church every evening throughout Lent. for the devotion of the people, some [of the captains] having seen and heard [them] to their satisfaction, they allocate 8 lire which ... are to be given to Antonio d'Alesso and [Antonio d'Adamo] ${ }_{22}$. on the condition that they provide the singing for all of the said Lent. ${ }^{22}$

In 1492, the captains of the Company of Sant'Agnese gave one of their singers a retroactive raise when they decided that his ability was sufficiently improved:

... Giovanni di Francesco, wool weaver in Piazza Santo Spirito, has served as "laudiere" of the said Company for some time at the rate of 10 
soldi [ $1 / 2$ lira] per month, and being much improved in his job and singing better, thereby the [captains] have cause to retain him to sing... at the rate of 14 soldi per month. ${ }^{23}$

In 1379 , the Company of Orsanmichele promptly lowered the salaries of their ferial singers after noting that "those who sing every evening in the oratory ... are very well paid, and that such a salary is not merited by such poor work." 24 The pious merchants who made these decisions understood well that in both the secular and sacred arena, quality was essential to good business.

In 15th-century Florence, business is primarily what lauda singing had come to be. The popularity of the devotion declined as more private expressions of piety and patronage took precedence, ${ }^{25}$ while economic contraction and increased taxation undercut the material wealth of the companies. By about 1440, the companies had abandoned all forms of lauda singing that were not directly supported by bequests: the schools, the Sunday processions, and all accompanying instruments except the organ disappeared. The bequests for lauda vigils had begun to taper off. Most telling of all, in the 1440s all but the two largest companies abandoned their ferial services, which had once been the core of their activity.

Largely on the strength of bequests, lauda singing continued throughout the century, even expanding into the larger polyphonic ensembles of the late 15 th century. But the companies also came under the hostile scrutiny of an increasingly centralized government that suspected them of harboring seditious political factions. ${ }^{26}$ The companies experienced periodic suppressions during the early 15 th century, but as the Medici consolidated their covert rule of the city in the second half of the century, the tactic, perfected by Lorenzo, became infiltration. Among the Medici's many partisans was the organist Antonio Squarcialupi, and Medici correspondence in the spring of 1445 reveals the city's leading musician reporting to the family on the secret voting procedures of one lay company. ${ }^{27}$ The company is not specified, but it well may have been the Cathedral company of San Zanobi. Besides serving as Cathedral organist since 1432, Antonio was also a member and frequent captain of the Company between 1436 and 1448, and was admonished by Company leadership on at least one occasion for “disobedience." During Lorenzo's unofficial rule of the city between 1469 and his death in 1492, he was the nominal member of at least eight lay 
companies, among them the laudesi companies of Santo Spirito, Sant'Agnese, and San Zanobi. The Company of Sant'Agnese benefitted from Lorenzo's generous patronage, and in turn frequently elected him to its major offices, and later admitted to membership and office-holding his sons Piero and Giuliano, his nephew Giulio (later Pope Clement VII), and the Florentine chancellor Bartolomeo Scala. ${ }^{28}$

With the rise to power of the Dominican friar Savonarola after the Medici expulsion in 1494, the companics paid heavily for their connections to the Medici. Then and throughout the early 16th century they were caught in the seesaw of political power that marked the final, convulsive years of the Republic, and the rise of the Medici dukes. In the face of long periods of closure and the confiscation and destruction of income generating property, the companies struggled, and for the first time were unable to meet the terms of their bequests. In 1508, the Company of Sant'Agnese complained of

... the ruin and great disruption of our company, since we could not perform the necessary business at the appropriate times... the business being...the satisfaction of the obligations and bequests of those who have willed movable and fixed property to the company in order to celebrate Divine Offices, or [to distribute] charity, or to recite laude for their souls, and they await the above intercessions and help. ${ }^{29}$

In addition, lauda singing had become a difficult and expensive activity to maintain, and one by one the companies relinquished their lauda bequests to the clerics of their host church, or substituted for it the increasingly popular charity of providing dowries. In 1538, the Company of Santa Croce recorded the

... very great difficulty that [now] occurs because there is no longer the abundance of singers that we once had, and in observance of this difficulty we wish to conduct in place of the singing of laude a charity of 25 lire per year to be given to the daughter [of one] of our brothers who is in need at the time of her marriage. ${ }^{30}$

By the late 16th century, the Company of Sant'Agnese was paying the Carmine friars to fulfil the liturgical obligations of its bequests, because

... the singers of laude not being content with the small wages and the salary that was given to them, it was necessary to dismiss the singing of laude as a thing that was not obligatory. ${ }^{31}$ 
With their abandonment of lauda singing in the 16th century, the Florentine laudesi companies severed their ties to the ancient tradition that had originated with them. As a layman's song at the heart of a lay, vernacular liturgy, and as the free expression of a socially and politically activated laity, the devotion and business of lauda singing declined along with the pluralistic guild society in which it had flourished. The decline of the lay companies themselves, however, gave way to transformation as they slowly rebuilt in the vastly changed society of grand ducal and CounterReformation Florence. ${ }^{32}$ The older confraternal traditions, like lauda singing, receded into the background of company activity or disappeared altogether, and new generations of Florentines, lacking contact with or committment to the older traditions, reorganized the companies according to new perceptions of picty and community based on principles of hierarchy, class distinction, and obedience. The older, citywide companies, like the laudesi and disciplinati, tended to become clite, neighborhood groups under the control of the duke.

By 1566 , lauda singing had come full circle in the 240-year-old history of the Company of San Frediano. The devotion having moved to the centre of Company activities in the late 14th century, it had now returned to exactly the role it had been assigned in the Company's 1324 statutes, when laude were sung only on the feast of San Frediano (AD 42, f. 34v). But the late 16 th-century character of the Company could not be further removed from its origins. Once a modest company with strong roots in the local, workingclass parish, officers were now required to hold the rank of "Dottore," "Cavalicre" (nobility), or a high-placed city official, and members had to be

...persons of good quality and reputation, and must not be or have been grave-diggers, or messengers or employees of the commune, or of any magistrate of the city of Florence. ${ }^{33}$

The once rich social and political character of the laudesi companies is revealed in a 14th-century inventory of the Company of San Zanobi, which included among those items intended to be borne forth in civic processions and displayed near the altar during feast days a gold star with escutcheons of the 21 guilds, and escutcheons showing the arms of the Company, the Commune, Liberty crowned, the Guclph Party, the King of France, the Church, Pope Urban V, and the "Popolo" (SZ 2176, f. 45r). This essential and complex backdrop to laudesi devotion had eroded by the 16th century; 
in 1546 the Company's disorderly state was the pretext under which the Grand Duke assumed control of the Company, ${ }^{34}$ and by 1555 lauda singing had become an optional devotion heard only on the feast of their patron saint (Cap 155, ff. 29-30).

The chief sponsors of traditional confraternal life, the friars, receded in the face of the advancing forces of despotic government and diocesan clergy. The torch of religious renewal, having reached its most distant bearer in the hands of the lay companies, now returned to the upper levels of the church hierarchy. An elite corps of priests, the Jesuits, administered a Counter-Reformation version of the affective devotion that had originated long before among friars and laymen, just as the lauda, for centuries the symbol of lay religious activism, was now a clerical song.

\section{Colby College}

Manuscripts
ASF
Archivio di Stato, Firenze
AD 41
AD 42
ASF, Acquisti e Doni 41, [Memoriale, 1488]
AD 44
ASF, Acquisti e Doni 42, [Capitoli, 1565]
Cap 155
ASF, Acquisti e Doni 44, Capitoli, 1584-1643
Cap 874
ASF, Capitoli 155 [1555]
Cat 291
ASF, Capitoli 874 [1445-1538]
ASF, Catasto vol. 291
Cort
Cortona. Biblioteca Comunale, 91
Mgll
OSM 11
Florence. Biblioteca Nazionale, Banco Rari 18 (olim Magl.II.I.122)
SA
SA 4
SA 24
SA 29
SF 4
ASF, Archivio dei Capitani di Orsanmichele, vol. 11, Partiti 1379-1380
ASF, Compagnie Soppresse, Archive 1: Compagnia di S. Maria delle Laude detta di S. Agnese
SMN 311
ASF, SA vol. 4, Partiti, 1483-1509
ASF, SA vol. 24, Entrata e Uscita, 1440-1447
ASF, SA vol. 29, Beni, 1488 [1460 f.]
ASF, Compagnie Soppresse, Archive 5: Compagnie di S. Frediano detta la Bruciata, vol. 4: Partiti, 1436-1469
SSP 78
ASF, Corporazioni Religiose Soppresse No. 102 [Santa Maria Novella archive, which contains vols. pertaining to Company of San Piero Martire], vol. 311, Debitori e Antichi [1329 ff.]
SZ
SZ 2170
SZ 2176
SZ 2186
ASF, Compagnie Soppresse, Archive 2: Compagnia di S. Maria delle Laude e Spirito Sancto detta del Piccione, vol. 78: Ricordi, 1444-1521 ASF, Compagnie Religiose Soppresse, Z.I., San Zanobi di Firenze ASF, SZ vol. 2170, fasc. 1, Statuti, 1326-1490
ASF, SZ vol. 2176, fasc. 12, Ricordi e Partiti, 1378-1383
ASF, SZ vol. 2186, fasc. 48, Tratte di Doti, Partiti, 1427-1438 


\section{Notes}

1 Giovanni D. Mansi, Sacrorum conciliorum (Paris: H. Welter, 1901-27; Graz: Akademische Druck, 1960-61), vol. 23 (1225-68), col. 865.

2 The terms "confraternitas," "fraternitas," and "congregatione" appear in formal Latin documents, but I have opted for the English translation of "compagnia," the term preferred by the laudesi themselves, and which reflects the dominant model and experience of the mercantile company.

3 This interaction is discussed in the author's dissertation, "Music and Merchants: The Laudesi Companies of Republican Florence, ca. 1270-1494" (Ph.D. diss., Indiana University, 1987), which is being prepared for publication by Oxford University Press.

4 Generally, though not unanimously, believed to have belonged to the Cortonese laudesi company at the Church of San Francesco. Facsimile edition in Fernando Liuzzi, La lauda e i primordi della melodia italiana (Rome: La libreria dello stato, 1935), vol. 1; recent edition of texts with commentary in Giorgio Varanini, Luigi Banfi and Anna Ceruti, eds., Laude cortonesi dal secolo XIII al XV (Florence: Olsch ki, 1981-85), vol. 1.

5 Facsimile edition in Liuzzi, La lauda, vol. 2, and recent transcription of the melodies in John Henry Grossi, "The Fourteenth Century Florentine Laudario Magliabechiano II.I.122 (B.R. 18): A Transcription and Study" (Ph.D. diss., Catholic University of America, 1979). The miniatures in this and another Florentine laudario (belonging to the Company of San Gilio) are examined in Vincent Moleta, "The Illuminated Laudari Mgll and Mgl2," Scriptorium 32 (1978): 29-50.

6 Nino Pirrotta, "Ars Nova and stil novo," in Music and Culture in Italy: From the Middle Ages to the Baroque (Cambridge, Mass.: Harvard University Press, 1984), p. 35.

7 Both pieces are in Mgll, ff. 116r-19r (Liuzzi, vol. 2, LXXVI-LXXVII). Originally the ballata form of the lauda would have been performed responsorially, as an alternation between a chorus of confratelli on the refrain and soloists on the strophes, but by the 15th century in Florence the performance of strophe and refrain alike had passed into the hands of paid soloists. Early lauda manuscripts transmit up to as many as 50 strophes for a single poem, but 14th-century Florentine companies apparently opted for greater musical length and complexity and many fewer strophes, a much accelerated change of a kind that occurred in the responsorially performed psalms of the Mass (Gradual and Alleluia) during the first millennium.

8 The figures under "assets" refer to florins, according to the Florentine Catasto (property tax) of 1427. Orsanmichele was a lay institution until 1415, when it became a collegiate church. The Company and church of S. Gilio were located within the hospital of Santa Maria Nuova. The companies of Sant'Agnese, Santo Spirito, and San Frediano were situated in the Oltrarno, and the small church of S. Frediano referred to here (which no longer exists) is distinct from S. Frediano in Cestello, a larger church in the same quarter of the city.

9 Daniel D'Avray, "Sermons to the Upper Bourgeoisie by a Thirteenth-Century Franciscan," in Studies in Church History, vol. 16, ed. D. Baker (Oxford: B. Blackwell, 1979), pp. 198, 204-16; Wilson, pp. 45-46.

10 Giovanni Villani, Cronica di Giovanni Villani a miglior lezione ridotta, ed. F. Dragomanni (Florence, 1844-45), Book 7, Ch. 154. 362 ff. About 12 lire could pay the rent on a small house in 14th-century Florence. The Company of Sant'Agnese, meeting at the Carmelite church across the river from Orsanmichele, experienced the same transition which is related in its 16th-century statutes:

... because some [men and women], out of devotion, met in the said church of the Carmine to sing laude spirituali, they took the name "delle laude," and because they received alms and bequests, it was decided that the Captains and officials should meet on certain prescribed days to conduct works of mercy and distribute alms.... [AD 44, ff. 5r-v] 
11 There are two extant versions of the document. one in the Orsanmichele records: Savino La Sorsa, La compagnia d'Or San Michele (Trani, 1902), pp. 208-209; the other in the San Piero Martire records: SMN 311, ff. 13r-14v.

12 The 14th-century statutes of San Zanobi are edited in Luciano Orioli, Le confraternite medievali e il problema della povertà (Rome: Edizioni di Storia e Letteratura, 1984), pp. 21-43.

13 Company of San Zanobi, 1326 statute (SZ 2170, f. 4v; ed. in Orioli, pp. 23-24).

VI. Come si raunino ogni sera in Santa Reparata. Anche ordiniamo et fermiamo che tucti quelli di questa conpagnia si debbiano ogni sera raunare nella chiesa predecta di madonna santa Reparata a cantare alchune laude cum ave maria ad honore di dio et della nostra donna. Ma quello che non venisse la sera ala chiesa predecta a cantare le laude come decto è di sopra debbia dire in honore di dio et della nostra donna tre pater nostri cum Ave maria.

14 This distinction is clearly made in the many laudario references and descriptions contained in the surviving inventories and statutes; Wilson, pp. 112-15.

15 Company of Orsanmichele, 1333 statute (La Sorsa, p. 196).

XIV. De l'uficio de' governatori de le laude. L'uficio de' governatori de le laude sia d'assettare e d'ordinare come si cantino ogni sera le laude dinanzi all ymagine della nostra Donna al pilastro sotto la loggia, e in fare la scuola per le domeniche per imparare e perchè imparino a cantare le laude. E cantinsi nella casa della Compagnia dinanzi alla ymagine della nostra Donna. E possano chiamare uficiali quanti e quali vorranno; a' quali governatori siano tenuti d'ubidire i laudesi secondo i capitoli, che saranno loro conceduti per gli rectori e capitani di questa Compagnia.

16 These are recorded in two books of bequests: SMN, vols. 306 (Debitori e Creditori, 1445-1454) and 326 (Testamenti, 1421-1423).

17 SSP 78, glued to inside of front cover.

18 Company of San Frediano, bequest of frate Giovanni Lozzi di San Pagolo, 1415 (AD 41, fr. $2 v-3 r)$.

Sono obligati e capitani di san friano che pel tempo saranno ognanno imperpetuo la prima domenica dopo el di di san friano far cantare le laude nella chiesa di san friano con una vigilia per l'anima di decto fra giovanni. Essi di poi aggiunto per consuetudine in decto de dare le bruciate, et fare la sera nella compagnia nostra una collatione a preti et a laudieri et a gluomini della compagnia, spendesi comunemente intucto L.octo in circa.

The bequests of friars to the companies for lauda vigils (e.g. in this case, as well as 6 of the 93 managed by San Piero Martire mentioned above) presents a striking reversal of traditional roles, with the cleric purchasing the efficacious prayer and ritual of the layman.

19 Cat 291, fr. 72r-v. Ser Piero (also a notary) was the son of Giovanni Mazzuoli, or Giovanni degli Organi, a prominent Florentine composer; Frank D'Accone, "Una nuova fonte del'ars nova italiana: il codice di San Lorenzo, 2211," Studi musicali 13 (1984): 10-11, 15-17.

20 A good deal of information on the Florentine singers at the three largest laudesi companies has been published in two articles by D'Accone, "Le compagnie dei Laudesi in Firenze durante l'Ars nova," in L'Ars nova italiania del trecento, vol. 3, ed. F.A. Gallo (Certaldo, 1970), pp. 253-80 and "Alcune note sulle compagnie fiorentine dei Laudesi durante il Quattrocento," Rivista italiana di musicologia 10 (1975): 86-114. Additions to this along with information about the singers at the three oltramo companies is set forth in Wilson, $\mathrm{Ch}$. 4.

21 There are detailed profiles in Wilson, pp. 251-59.

22 Company of San Frediano, Captains' election of laudesi for Lent, March 26, 1441 (SF 4, f. 23r). 


\section{0 / Renaissance and Reformation}

Item decto di et hora in mantanente i detti capitani avendo electi et ordinata due a cantare laude nella decta chiesa ogni sera, tutta la quaresima, per devotione de popoli, avendo veduto e udito per coloro in parte essi bene satisfatto, stantiorono loro lire otto, che alloro sieno date [sic], cioè, Antonio d'Alesso e Antonio d'Adamo [deleted].... con conditione che forniscano di cantare tutta la decta quaresima.

23 Company of Sant'Agnese, Captains' decision to raise the salary of a laudese, September 23, 1492 (SA 4, f. 52v).

Item e prefati capitani atteso che giovanni di francescho [lacuna] tessitore di pannilini in sulla piaza di santo spirito, ha servito per laudiere decta compagnia più tempo ad ragione di s.dieci el mese, et essendo migl[i]orato gli labore assai, et cantare meglio, per haver cagione di fermallo a cantare, per loro solenne partito vinto tralloro per tucte fave nere.. - gl'acerebbono per l'avenire s[oldi] quattro per tucto el tempos $<\ldots$. i condocto a cantare in nostra compagnia... sono per tucto ad ragione di s[oldi] quattordici.

In the following year, the same Company granted an official appointment and retroactive pay to a singer who had been serving on probation for six months:

...the captains, seeing that Domenico di Lionardo Tavolaccino has already sung as a laudiere for 6 months with the hope of being hired, and the above captains understanding that [they would do] well to hire him because he is a good laudiere... [they] agree to hire the said Domenico as laudiere... at the rate of 10 soldi per month, with the usual fines [for absences], and they allocate 3 lire for the said 6 months that he sang without having been elected (SA 4, f. 56v).

24 OSM 11, f. 5v; ed. in D'Accone, "Le compagnie," p. 272.

25 Gene Brucker, Renaissance Florence (New York: J. Wiley, 1969), p. 227.

26 Lorenzo Polizzotto, "Confraternities, Conventicles and Political Dissent: The Case of the Savonarolan 'Capi Rossi'," Memorie domenicane new series 16 (1985): passim.

27 The letter is from Ugo della Stufa to Giovanni de' Medici, dated April 3, 1445; ASF, M(edici) $\mathrm{A}$ (vante il) $\mathrm{P}($ rinc.), F.V., c. 590). The letter is partly transcribed in Bianca Becherini, "Un canta in panca fiorentino: Antonio di Guido," Rivista musica italiana 50 (1949): 245.

28 Ronald Weissman, Ritual Brotherhood in Renaissance Florence (New York: Academic Press, 1982), pp. 170-72; Wilson, pp. 361-63.

29 Edited and partly translated in Weissman, p. 187.

30 Company of Santa Croce, 1538 statute (Cap 874, ff. 39r, 40r-v).

$\ldots$ Da un temp $<0\rangle \mathrm{q}<\ldots . .>$ son $<$.. $>$ tate con grandissima difficultà advenga che no[n] ha più quella copia di cantori che per il passato havevamo $\langle\ldots\rangle$ vedut $\langle$.. $\rangle$ la difficultà, vogliamo in iscam<bio > di cantare le laude, si facia un limosina di lire venticinque ogn $<$ ianno $>$, la quale si hab $<$ bia $>$ a dar $<$ e a una figluo $>$ la $c h<\ldots$. no de[i] nostri fratelli che sia bisognosa quando si marita; [f. 39r]: Ma perchè a que[i] tempi erano più prosper $\langle i>$, e le persone più divote che al presente non sono. Et maximamente che habbiamo inteso da $\mathrm{e}<\ldots . .$.$\rangle che non riccordono mai tal <\ldots . .>$ nia o ordine essersi $\langle\ldots\rangle$ la difficultà et imposs $\langle$ ibili $\rangle$ tà $\langle\ldots .$.$\rangle , non vogliamo ancor noi esser tenuti et$ obligati all antico ordine.

(The original text is badly damaged, and I have taken some liberties with the translation since the intent of the document is clear).

31 Company of Sant'Agnese, 1584 statute (AD 44, f. 33r).

XIIII. Delli oblighi della Compagnia e osservanza de[i] legati. ... Trattando adunque del primo, si dice che al tempo che questa Compagnia cantava o faceva cantare le Laude, fur[o]no diversi Testatori che lasciorno a questa piủ beni immobili con obligo fra l'altre cose di fare dire doppo le laude alli frati del Carmine una vigilia, overo Notturno de[i] Morti, et che si d'esse loro tanta cera in Candele, quanta per detti Testamenti è espresso. Occorse doppo, che non si contentando di Cantori delle Laude, delli piccoli prezzi, et 
salarii che si davon[o] loro, fu di necessità dismettere il cantare [del]le laude dette come cosa che non era d'obligo. Onde che si convenne con li frati che essi dicessino la medesima vigilia, et Notturno de[i] Morti, et certe feste ordinate da detti testatori, et havessino el prezzo medesimo che dal Testatore era ordinato, si spendesse et essi mettessino la cera di loro....

32 The decline and transformation of the lay companies are discussed in Weissman, pp. 173 ff., and Wilson, Ch. 7; Marcia B. Hall effectively evokes the changed social and political atmosphere of 16th-century Florence: Renovation and Counter-Reformation: Duke Cosimo and Vasari in Santa Maria Novella and Santa Croce 1565-1575 (Oxford: Oxford University Press, 1979), pp. 1-15.

$33 \mathrm{AD} \mathrm{42,} \mathrm{f.} \mathrm{23r-v:} \mathrm{"...} \mathrm{[novizi]} \mathrm{sieno} \mathrm{persone} \mathrm{di} \mathrm{buona} \mathrm{qualità} \mathrm{et} \mathrm{fama,} \mathrm{et} \mathrm{che} \mathrm{non} \mathrm{sieno} \mathrm{o}$ sieno stati beccamorti o messi o famigli del Comune o di alcuno magistrato della Città di Firenze."

34 Weissman, pp. 200-201. 